\title{
Management Strategies for Funding and Sustaining Early Childhood Education in Nigeria
}

\author{
Alabi, A. T. ${ }^{1, *}$, Ijaiya, N. Y. S. ${ }^{1}$
}

(C) Uganda Martyrs University

\begin{abstract}
This paper examined the existing management strategies for funding Early Childhood Education (ECE) in Nigeria with a view towards its better funding and sustenance. It recognised the commitment of the Nigerian Governments and the support of the community, individuals and foreign sponsors in funding ECE programmes. It argued that, nevertheless, much more needs to be done towards providing adequate funds for quality teachers/ caregivers, supply of appropriate facilities and stimulating learning materials as well as supervision of ECE programmes. Towards this end, increased government allocations, sustained international support, financial allocation to ECE teacher training institutions, equity funding and cost-sharing strategies were recommended.
\end{abstract}

Keywords $\cdot$ Early Childhood Education $\cdot$ Management Strategies $\cdot$ Funding

\section{Introduction}

Education is increasingly attracting more attention all over the world as the bedrock of human capital development and knowledge economy and taking care of the child's development right from birth is now recognized as the best option as a starter. Thus, the nature and intensity of care, nutrition and stimulation a child receives during this period determines to a large extent the level of physical, cognitive and psychosocial development a child can attain (UNICEF Nigeria, Undated). The learning process starts from the parents at home and then moves to the teachers in the school.

Early Childhood Education (ECE), also called Early Childhood Care and Education (ECCE) in China and Integrated Early Childhood Development (IECD) in Nigeria, refers to the education that children receive during the early stage of their childhood (REAP,2001). Early Childhood Education could also be a major input into a child's formal education. The importance of Early Childhood Education includes development of mental functions of children in areas such as language, motor skills, psychosocial, cognitive and learning (Bowman, Donovan and Burns, 2001). Furthermore, Early Childhood Education

\footnotetext{
${ }^{1}$ University of Ilorin, *Corresponding author: alabiafusat@yahoo.com
} 
develops in children school readiness, with positive economic and social impacts lasting well into adulthood from higher education attainment and less chance of involvement in criminal activities, to higher status employment and higher earnings (Schweinhart, 2007, Sparling, Ramey and Ramey, 2007).

In the National Policy on Education, the Federal Republic of Nigeria (2004), Early Childhood Education is labelled as Pre-primary Education and is defined as the education given in an educational institution to children aged three to five plus prior to their entering the primary school. As stated in the policy document, the purpose of pre-primary education includes, among others:

1. Providing a smooth transition from the home to the school;

2. preparing the child for the primary level of education;

3. providing adequate care and supervision for the children while their parents are at work;

4. Inculcating in the child the spirit of enquiry and creativity through the exploration of nature, and the local environment, playing with toys, artistic and musical activities, etc.

5. Teaching the rudiments of numbers, letters, colours, shapes forms, etc. through play, and

6. Inculcating social norms.

Appropriate levels of Government (State and Local) are required to establish and enforce educational laws that will ensure that established pre-primary schools are well-run, preprimary teachers well qualified, and other appropriate academic infrastructure provided.

The vital roles played by early childhood education in the overall development of a child are recognised all over the world. This is evident in the attention and committed efforts on early child education in these countries- New Zealand, Gambia, Senegal, Mali, Zambia.

Nigeria also signed up to the Jomiten Declaration on Education for all (EFA) in 1990, to provide comprehensive Early Childhood Education and Care for all pre-primary schoolers. Early childhood Education, now included in the UBE programmes requiring every public school to have a pre-primary linkage, had hitherto been an exclusive preserve of the private sector. Though, Early Childhood Education is included in the National Policy in Education (1981, 1998, and 2004), the Federal government of Nigeria showed more commitment with the inauguration of the Early Childhood Education Policy in 2004.

To achieve these laudable objectives of Early Childhood Education requires provision of basic resources such as qualified and competent teachers and care givers as well as appropriate learning environment in terms of space, security/safety and materials for playing/learning. Adequate provision of these resources requires adequate funds. This paper is therefore focused on the existing funding strategies of early childhood education in Nigeria, with a view to suggesting appropriate funding strategies for effectiveness of Early Childhood Education.

\section{Concept of Early Childhood Education}

Early Childcare and Development has been variously defined (Uzodinma and Akinware, 2001): 
1. The education provided for children 0-3 years in Day Care centres and for 3 years to less than 6 years in Nursery schools.

2. A community-based, low-cost project for the holistic development of the child from 06 years.

3. A comprehensive approach to policies and programmes for children from birth to 8 years of age, their parents and caregivers with the purpose of protecting the children's rights to develop their full cognitive, emotional, social and physical potentials.

Early Childhood Development is also perceived as the foundation of human development, economic growth, social change and transformation in Africa (Aidoo, 2008). Literature reveals that there are three types of Early Childhood Education which are either homebased or centre-based. These are:

1. Day care education

2. Nursery school education and

3. Kindergarten education

Day care education is given to children of 0-2 years while Nursery school education is offered to children of ages 3-5 years. Kindergarten education is an integral part of Nursery education and generally restricted to children aged 5 years. It is a preparatory class for formal primary school education.

Early Childhood Education is flexible in structure with baby-friendly and learning friendly environment. The infrastructure has specification and varieties with tender and sensitive furniture. The establishment and management of Early Childhood Education centres are facilitated and regulated by government rules and regulations, which ensure standardization but very little uniformity.

In Nigeria today, with the incorporation of Early Childhood Education into the UBE programme in 2004, every public primary school is to integrate Early Childhood Education into its programme. This integration is backed up by government financing and supported by the community, individuals and foreign sponsorship. For instance, three states in the Federation namely Kwara, Kaduna and Kano were given special World Bank Grant in 2008-2011 to set up model Early Childhood Education centres. In Kwara state, model Early Childhood Education is run in public schools with support mainly from the national purse through counterpart funding and international agencies such as the World Bank, UNICEF, and ESSPIN (Education Sector Support Programme in Nigeria).

\section{Funding of Early Childhood Education}

Funding is very crucial to achieving success in any public service. In a study conducted by Alabi (2003) on Evaluation of Universal Basic Education Process on Primary School Enrolment in Kwara state, Early Childhood Education was not implemented at all. Among the reasons for zero percent implementation had to do with funding policies. In Early Childhood Education, adequate funds need to be made available for provision of many resources. These resources include: facilities and stimulating materials for teaching, training and re-training of staff (teachers and caregivers) in appropriate institutions such as colleges of education and universities), enrichment and sensitization of programmes through regular workshops, monitoring, uniforms, feeding, immunisation, supervision and inspection, report writing, publications, school meals and training manuals. As rightly 
observed by Ijaiya (2001), with adequate resources, access to education can be increased while quality suffers with poor funding.

In developed countries, the funding of pre-school education is usually given a prime place in the nations' budgets. America for instance estimated the cost of providing a quality preschool education to be $\$ 70$ billion a year with annual cost per child of about $\$ 8,700$ (Ajayi, 2008). Likewise in Ireland, the total funding made available for childcare is 436.7 million Euros ( $\$ 580$ million). Other countries that realised the economic and social benefits of pre-school education and invested greatly in it include Brazil, Zambia, Niger, South Africa and Ghana (Ramires, Paira and Almeida, 2009).

With permission granted for private efforts in the provision of pre-primary education in Nigeria, the resultant Day Care centres and Nursery/primary schools are profit-oriented and self-financed. Proprietors run the schools with finances from school fees and other levies charged the parents. The fees could range from $\$ 500$ per month to $\$ 5,000$ or above especially in the urban metropolis like Lagos. The better the facilities, the higher the fees they charge. For the neighbourhood type (Jele o simi in Yoruba) as well as Nursery schools in the rural areas, fees are charged according to how interested parents can afford. The "Jele o simi" group, for instance started with 10 per day per child (now upgraded to between $\$ 20$ and $\$ 50$ per day) in Ilorin metropolis. Many parents are poor and unable to pay even the minimal fee of $\$ 20$. Due to accruing meagre finances, the children are usually cared for by one or at most two untrained caregivers who do it to earn a living. Children are kept in crowded environment, chorusing alphabets to keep them busy between $8 . a m$ and $1.00 \mathrm{pm}$ or later in other places until their parents come for them. So, in such an un-conducive environment, little is learnt by the children. Same goes for the learning environment of rural Nursery schools where facilities and quality of teachers are usually below standard. With possibly the exemption of the few Nursery schools established by some universities, colleges of education, companies and a few rich individuals, the quality of facilities and staff is generally low (Ejieh, 2006). In terms of financing, therefore, parents and local communities manage and run these centres with minimal financial resources and inadequate materials.

With the emergence of public Early Childhood Education integrated into public primary schools, government's participation and ownership are expanding, courtesy of the UBE Act (2004). Funding is mainly through FGN-UBE counterpart funds where both federal and state governments supply funds to Basic Education. According to UBEC (2009), this is the first time that Basic Education has a quantum of funds being pumped into it. Sources of financing are both external and internal.

\section{Internal Sources}

UBE Intervention Fund from the Federal Government of Nigeria's Consolidated Revenue Fund. Table 1shows the FGN/ UBE Matching Grant between 2006 and 2010.

Table 1: Budgetary Allocations from the FGN-UBE Matching Grant (2006-2010)

\begin{tabular}{llll}
\hline Year & Releases & Disbursement & Not accessed \\
\hline 2006 & $21,336,000,000$ & $21,308,459,363$ & - \\
2007 & $24,710,000,000$ & $24,041,404.787$ & $668,295,213$ \\
2008 & $30,800,000,000$ & $23,119,020,296$ & $7,680,979,703$ \\
2009 & $19,651,500,000$ & $10,776,863,151$ & $8,874,636,849$ \\
2010 & $23,042,932,729$ & $4,668,022,704$ & $18,374,910,024$ \\
Total & $119,54,04,32,729$ & $83,913,770,301$ & $35,598,821,788$ \\
\hline
\end{tabular}

Source: UBEC (2011) update on the Activities of UBEC 
The UBE law stipulated that $5 \%$ of these grants are allocated to Early Childhood Education and Development in all the 36 states and the FCT. However, the drawback here is that many states have been found wanting in honouring the system of counterpart funding put in place to boost UBE implementation. This development has drawn the displeasure of the Federal Government and the Minister of Education in recent times. In fact, a recent meeting of the Minister of Education with State Governors centred mainly on educating the latter on the counterpart funding and the way States' attitude is adversely affecting the implementation of UBE, including ECCD. Other internal sources of funding may include complementary funding from State and Local Governments; funds or consolidated contributions in form of Federal guaranteed credits; local individual/corporate, as well as international donor grants; and contributions for privately owned ECD centres, Nurseries and Pre-Primary Schools, by communities, NGOs and private individuals through personal savings loans (UNESCO/ IBE, 2006).

\section{External Sources}

External sources of funding for ECD may include the following:

1. World Bank - providing grants for Early Childhood Education model centres and training of teachers, caregivers and stimulating materials through school grant.

2. UNICEF and UNESCO - in some local communities

3. Education Sector Support Programme in Nigeria (ESSPIN) under DFID - technical support. For example, involved in 'turn around' of College of Education, Oro in Kwara State for the training and production of Early Childhood Education teachers as well as curriculum development for NCCE.

In spite of these varied sources of funding, much more still need to be done in terms of quality of Early Childhood Education teachers and caregivers, supply of facilities and learning materials to provide a conducive learning environment, monitoring/supervision of ECCD programmes as well as production and distribution of appropriate manuals, materials and publications.

\section{Funding Strategies for Early Childhood Education Programmes}

To be able to generate adequate funds to turn around Early Childhood Education for good, the following funding strategies are recommended:

\section{Increased Government Allocation}

As given a prime place in the developed nations' budgets, ECCD needs to be specially budgeted for and/or increase its percentage of UBE matching grant to at least $10 \%$. This is necessary in view of the recognised immediate and long-term benefits of Early Childhood Education to the recipients such as improved cognitive abilities, social and motor skills (Osakwe, 2009). Such increased funds should be focused on improving the quality of all resources - human and material- to provide a more conducive environment for the achievement of Early Childhood Education objectives. There is thus the need to make realistic budget for ECCD subsector. The Nigerian education budgets may need to be substantially increased and or increased percentage accorded to preschool programmes. 
State Governments also need to improve their attitude to counterpart funding system to make it work for ECCD.

\section{Sustained International Support}

Various international organisations have contributed funds, materials and technical support to get Early Childhood Education to its present level/status in Nigeria. Such organisations include UNICEF, UNESCO, ESSPIN and World Bank. In order to sustain and possibly increase such contributions, efforts need to be made by the various governments and their agencies (UBEC, SUBEB etc) towards prudence and accountability in their use of such supports. The donors should insist on at least two years of independent private monitoring and fund it.

\section{Financial Allocation to Early Childhood Education Teachers Training Institutions}

One of the major oversights of the government in educational planning is the unpreparedness of the right teachers for policy implementation. It has been the bane of educational development (Ijaiya, 2004). The ECCD suffered the same fate throughout Nigeria. Few educational institutions run Early Childhood Education as a discipline in Nigeria. In Kwara state for instance, College of Education, Oro is the only institution which started the programme in 2008 with the technical supports of ESSPIN. It is similar all over Nigeria. The states had to resort to transfer of primary school teachers to ECCD classes as an alternative even though most were not ECE professionals. Teachers hold the reign to the success of any educational policy, more so for 0-5 years. Therefore, more funds need to be directed to mount Early Childhood Education programmes in teacher education institutions. The extra allocation would be needed to equip the relevant sections of the institution with appropriate and adequate resources and materials to train Early Childhood Education teachers and caregivers.

\section{Equity Funding of Early Childhood Education Programmes}

Equity funding is recommended to take care of the various groups needing ECCD services as done in New Zealand. In that country, the groups include low socio-economic communities, children with special needs and non-English speaking backgrounds, language and culture other than English (NZ Education, 2011). In the case of Nigeria, groups to be considered should include low socio-economic factors, special needs children, destitute children, location (rural/urban) and proprietorship (private and public) of the centres.

\section{Financial Focus on Establishment of Early Childhood Education Centres}

For now, every public primary school should have a well-equipped section dedicated to Early Childhood Education so that it can be brought to parents' doorstep. With time, purely Early Childhood Education centres should be established to create the unique environment required for this level of education. This requires a lot of planning of which funds- immediate and sustained, constitute a very crucial part. In addition, matching grants and other grants should be given to communities to set up Early Childhood Education centres which are run at reduced cost to parents. 


\section{Cost- sharing among Stakeholders and Beneficiaries of Education}

Though it is good that the governments should shoulder a lot of responsibilities, the reality on ground is that Nigeria is still a third world country. It cannot afford to carry all the load of education and other competing sectors. There is therefore a need to share the cost of education.

Universal Basic Education Law implies that education is free but free education concept is a relative term. Education has never been free anywhere. So, if parents are feeding their children already, there is the need for nutritional education on the quality of meals that children need to grow and develop. Due to ignorance, many parents serve children meals that are not beneficial to the body such as garri, eba and especially biscuits children take to school that are laden with all sorts of additives and preservatives from the factory such as caffeine and colouring. Instead, parents and children should be educated in the school, on television, radio on the type of food needed by children. Nigeria is blessed with many fruits round the year. Schools can prescribe the fruits that are in season e.g. oranges, banana, carrot, apple, and garden egg for children to bring to school. On weekly or daily basis, teachers can tell children the types of snacks to bring to school at low cost. It will go a long way to educate the parents and children on the quality of food needed to grow and develop along the lines expected by ECCD.

\section{Conclusion}

The Federal Government of Nigeria has no doubt demonstrated more commitment to Early Childhood Education and Development (ECCD). This is evident from the inauguration of ECCD policy in 2004, backed up by government financing and supported by the community, individuals and foreign sponsorship. However, much more still needs to be done in terms of adequate funds for quality teachers/caregivers, supply of facilities and learning materials as well as monitoring of ECCD programmes.

\section{References}

Aidoo, A.K. (2008). Positioning ECD Nationally; Trends in selected African countries. In M. Garcia, A. Pence and Evans, J.L. (Eds.). Africa's future, Africa's challenge: Early Childhood Care and Development in Sub-Saharan Africa, (pp. 29-49). Washington, DC: World Bank

Alabi, A.T. (2003). Evaluation of the impact of Universal Basic Education process on primary school enrolment in Kwara state. Nigerian Journal of Educational Research and Evaluation, 4,(1), 7-12.

Ajayi, H.O. (2008). Early childhood education in Nigeria: A reality or a mirage? Contemporary issues in early childhood, 9, (4), 375-380, viewed 10 November, 2011, www. wwords.co.uk/pdf/validates.asp $? \mathrm{j}=\mathrm{cie} \& \mathrm{vol}=9 \&$ issue $+4 \&$ year $+2008 \& \operatorname{article}=11 \mathrm{~A}$ jayi_CIEC_9_4_web.

Bowman, B., M. Donovan and M. Burns (Eds.) (2001). Eager to Learn: Educating Our Preschoolers, Committee on Early Childhood Pedagogy, Commission on Behavioural and Social Sciences and Education, National Research Council, National Academy Press, Washington, DC. 
Ejieh, M.U.C. (2006). Pre-primary education in Nigeria: Policy implementation and problems. Elementary Education online, 5, (1), 56-64, viewed 5 November, 2011, http://ikogretim-online.org

Federal Republic of Nigeria (2004).National Policy on Education (4 ${ }^{\text {th }}$ ed). Lagos: NERDC Press.

Ijaiya, Y. (2001). From Quality Control to Quality Assessment: A panacea for Quality Education in Nigeria Schools in N.A. Nwagu, E.T. Ehiaetalor, M.A. Ogunu \& Mon Nwadiani (Eds). Current Issues in Educational Management in Nigeria. A publication of the Nigerian Association of Educational Administration and Planning.

New Zealand Ministry of Education (2011). Welcome to Early Childhood Education, Leadership, Management and Administration, viewed 12 November, 2011, www.mined.govt.nz.NZEducation/EducationPolicies/EarlycHildhood.aspx

Osakwe, R.N. (2009). The effects of early childhood development experience on the academic performance of primary school children. Stud Home Com Sci., 3,(2), 143147.

REAP (2011). Early Child Education, viewed 11 November, 2011, http://reap.standford.edu/docs/early_childhood_education

Ramires, V.R., Paira, M.G.G. \& Almeida, L. (2009). Early Childhood Care and Education: Worldwide Challenges and Progresses, viewed 23 October, 2011, http://www.tc.edu/cice/issues/11.00/PDFs/11completeissue.pdf

Schweinhart, L.J. (2007). "Outcomes of the high/scope Perry preschool Study and Michigan School Readiness Program” in Early Child Development From Measurement to Action: A Priority for Growth and Equity, M.E. Young (Ed), International Bank for Reconstruction/World Bank, Washington, DC.

Sparling, J., C.T. Ramey \& S.L. Ramey (2007). "The Abecedarian Experience” in Early Child Development From Measurement to Action: A priority for Growth and Equity, Ed. M.E. Young, International Bank for Reconstruction/World Bank, Washington, DC.

The UBEC Newsletter (2009). FGN-UBE Intervention.

UBEC (2004). 2004 Annual Report. Abuja: Universal Basic Education Commission.

UBEC (2011). Update on the activities of UBEC. A paper presented at the $57^{\text {th }}$ meeting of the National Council on Education (NCE) held in Sokoto, Sokoto State $\left(21^{\text {st }}-25^{\text {th }}\right.$ Feb).

UNESCO, IBE (2006). Nigeria Early Childhood Care and Education (ECCE) programmes. A country profile prepared for EFA Global Monitoring Report, 2007, $\begin{array}{lll}\text { viewed } & 15 & \text { November, }\end{array}$ www.unesdoc.unesco.org/image/0014/001472/14720ie.pdf

UNICEF Nigeria (Undated). The Children- Early Childhood Care and Education, viewed 6 November, 2011, www.unicef.org/nigeria/children_1931.html

Uzodinma, E.C.C. \& Akinware, M. (2001). Early childhood education: Indicators in the structure and content of the educational system of Nigeria, viewed 9 November, 2011.

\section{Author Biography}

Dr. Alabi, Afusat Titilayo is a Senior Lecturer at the Department of Educational Management, University of Ilorin, Nigeria. She is a registered member of Teachers Registration Council of Nigeria, National Association of Educational Administration and Planning, National Association of Educational Researchers and Evaluators, 
Commonwealth Council for Educational Administration and Management and Nigerian Institute of Management.

Prof. Ijaiya, N. Y. Sidiqat is a Professor of Educational Management, University of Ilorin, Nigeria. She is a member of the Teachers Registration Council of Nigeria, National Association of Educational Administration and Planning; National Association of Educational Researchers and Evaluators; and Commonwealth Council for Educational Administration \& Management. She has served as Head of Department, Director, Institute of Education, as a member of the Governing Council of Al-Hikmah University, Ilorin and Consultant on SABER Early Childhood Development (ECD) for the World Bank in 2012. 